\title{
Pengaruh Komunikasi Interpersonal dan Disiplin Kerja Terhadap Kinerja Guru
}

\author{
Suyeti Nilasari $1^{*}$, Happy Fitria ${ }^{2}$, Rohana ${ }^{3}$ \\ 1SMP Negeri 21 Palembang, Indonesia \\ 2,3 Universitas PGRI Palembang, Indonesia
}

Corresponding Author:@ suyeti240316@gmail.com*

\begin{tabular}{|c|c|}
\hline \multirow{10}{*}{$\begin{array}{c}\text { ARTICLE INFO } \\
\text { Article history: } \\
\text { Received } \\
\text { September 09, } \\
2020 \\
\text { Revised } \\
\text { October 24, } 2020 \\
\text { Accepted } \\
\text { October 26, } 2020\end{array}$} & ABSTRACT \\
\hline & This study determined the effect of interpersonal communication and \\
\hline & work discipline on teacher performance. This study used quantitative \\
\hline & methods. The sample of this research was 50 teachers of SMA Negeri 21 \\
\hline & Palembang. Data were collected through questionnaires, documentation \\
\hline & $\begin{array}{l}\text { study, and observation. Data were analyzed using classical assumption } \\
\text { test, multiple linear tests, coefficient of determination test and f-test. The }\end{array}$ \\
\hline & results of this study indicate that there is partially and simultaneously \\
\hline & significant effect of interpersonal communicat \\
\hline & the performance of teachers in SMA Negeri 21 Palembang \\
\hline & \\
\hline & $\begin{array}{l}\text { Keywords: Teacher's Performance, Interpersonal Communication, Work } \\
\text { Discipline }\end{array}$ \\
\hline How $\mathrm{t}$ & $\begin{array}{l}\text { Nilasari, S., Fitria, H., \& Rohana, R., (2020) Pengaruh Komunikasi Interpersonal } \\
\text { dan Disiplin Kerja Terahadap Kinerja Guru. Attractive : Innovative Education } \\
\text { Journal, 2(3). 15-20. }\end{array}$ \\
\hline Journal Homepage & https://www.attractivejournal.com/index.php/aj/ \\
\hline This is an o & icle under the CC BY SA license \\
\hline & https://creativecommons.org/licenses/by-sa/4.0/ \\
\hline Published by & \\
\hline
\end{tabular}

\section{PENDAHULUAN}

Guru adalah kondisi yang diposisikan sebagai garda terdepan dan posisi sentral di dalam pelaksanaan proses pembelajaran (Kristiawan \& Rahmat, 2018; Fitria dkk, 2019). Berkaitan dengan itu, maka guru akan menjadi bahan pembicaraan banyak orang, dan tentunya tidak lain berkaitan dengan kinerja dan totalitas dedikasi dan loyalitas pengabdiannya. Guru adalah salah satu komponen manusiawi dalam proses belajar mengajar, yang ikut berperan dalam usaha pembentukan sumber daya manusia yang potensial di bidang pembangunan (Yuliandri \& Kristiawan, 2017; Kartini \& Kristiawan, 2019). Oleh karena itu, guru yang merupakan salah satu unsur di bidang kependidikan harus berperan secara aktif dan menempatkan kedudukannya sebagai tenaga profesional, sesuai dengan tuntutan masyarakat yang semakin berkembang. Dalam hal ini guru tidak semata mata sebagai pengajar yang melakukan transfer ilmu pengetahuan, tetapi juga sebagai pendidik yang melakukan transfer nilai-nilai sekaligus sebagai pembimbing yang memberikan pengarahkan dan menuntun siswa dalam belajar.

Untuk mewujudkan dan menciptakan kinerja guru yang baik antar berbagai elemen sekolah harus terjadi komunikasi Berkomunikasi merupakan keharusan bagi manusia, karena dengan komunikasi kebutuhan manusia akan terpenuhi (Andriani, S., Kesumawati, N., \& Kristiawan, M. 2018). Menurut Johnson dalam (Sutikno, 2003) mengemukakan beberapa peranan yang disumbangkan oleh komunikasi antar pribadi dalam rangka menciptakan kebahagiaan hidup manusia yaitu Komunikasi antar

\section{Attractive : Innovative Education Journal}

Vol. 2, No. 3, November 2020

ISSN : 2685-6085 
pribadi membantu perkembangan intelektual dan sosial kita, Identitas atau jati diri kita terbentuk dalam dan lewat komunikasi dengan orang lain

Berdasarkan hasil observasi yang peneliti lakukan di, ada beberapa temuan yang peneliti sangat relevan untuk diteliti. Hasil observasi yang peneliti lakukan SMA Negeri 21 Kota Palembang, kinerja guru yang mengajar di sekolah ini terkesan biasa saja, bahkan untuk kegiatan belajar mengajar belum secara maksimal mencerminkan pembelajaran abad 21. Guru yang mengajar di kelas sebagian besar menggunakan metode belajar ceramah dan penugasan, ini artinya metode pembelajaran yang berlaku masih paradigma belajar model yang sangat sederhana dan tidak menunjukkan arah pembelajaran seperti yang dicanangkan dan diharapkan pemerintah dewasa ini.

Di sisi lain, gaya mengajar yang bersifat monoton seperti ini meninbulkan rasa jenuh dan bosan pada siswa, bahkan pembelajaran menjadi tidak efektif dan efesien, karena ditemukan siswa yang sibuk dengan aktivitasnya sendiri tanpa serius mengikuti pembelajaran yang dilaksanakan guru. Kondisi seperti ini menunjukkan bahwa terjadi beberapa fenomena dalam pembelajaran seperti pembelajaran menjadi tidak efektif, minat belajar siswa menjadi rendah, terjadi diskomunikasi antara guru dengan siswa, dan kurangnya interaksi atau komunikasi antara guru dan siswa dalam kegiatan pembelajaran Temuan lain yang peneliti dapati, dalam pelaksanaan pembelajaran dikelas, hanya ada beberapa orang guru yang mengajar dengan menggunakan media pembelajaran yang sangat sederhana, kondisi ini tentunya sebagai gambaran bahwa kinerja guru yang mengajar di SMA Negeri 21 masih tergolong rendah.

Berkaitan dengan ranah disiplin, berdasarkan hasil observasi peneliti menemukan beberapa permasalahan yang sangat signifikan dengan pelanggaran disiplin guru sebagai tenaga pendidik. Berdasarkan pantauan peneliti masih ditemukan guru yang datang terlambat ke sekolah, berpakaian tidak sesuai dengan peraturan yang telah telah ditentukan, ketika jam pergantian belajar sudah berbunyi, peneliti masih menemukan guru yang terkesan lambat menuju ruang kelas untuk melaksanakan kegiatan pembelajaran. Mereka masih sibuk dengan aktivitas mereka yang tidak ada kaitannya dengan persiapan pelaksanaan pembelajaran.

Bertolak dari temuan yang peneliti dapati, maka peneliti tertarik untuk melakukan penelitian lebih lanjut dengan memberi judul penelitian ini, peneliti tertarik untuk melakukan penelitian lebih lanjut dengan memberi judul penelitian ini "Pengaruh Komunikasi Interpersonal dan Disiplin Kerja Terhadap Kinerja Guru di SMA Negeri 21 Kota Palembang". Menurut Rivai dan Basri (2005) kinerja merupakan terjemahan dari kata performance yang didefinisikan sebagai hasil atau tingkat keberhasilan seseorang secara keseluruhan selama periode tertentu untuk melaksanakan tugas dibandingkan dengan berbagai kemungkinan, seperti standar hasil kerja, target atau sasaran atau kriteria yang telah ditentukan terlebih dahulu dan telah disepakati bersama. Pendapat tentang kinerja guru tersebut di atas senada dengan Mangkunegara, Anwar (2006) yang menyatakan bahwa kinerja (prestasi kerja) adalah hasil kerja secara kualitas dan kuantitas yang dicapai oleh seorang pegawai dalam melaksanakan tugasnya sesuai dengan tanggug jawabyang diberikan kepadanya. Senada dengan pendapat Sakban, S., Nurmal, I., \& Ridwan, R. B. (2019) memberikan pengertian kinerja sebagai tingkat pelaksanaan tugas yang dapat dicapai seseorang dengan menggunakan kemampuan yang ada dan batasan-batasan yang telah ditetapkan untuk mencapai tujuan organisasi. Pendapat ini didukung oleh Nawawi (2005) memberikan pengertian "kinerja sebagai hasil pelaksanaan suatu pekerjaanyang memberikan pema-haman bahwa kinerja merupakan suatu perbuatan 
atau perilaku seseorang yang secara langsung maupun tidak langsung dapat diamati oleh orang lain.

\section{METODE PENELITIAN}

Metode Penelitian yang peneliti gunakan pada penelitian ini yaitu metode penelitian kuantitatif. Metode penelitian kuantitatif merupakan studi yang diposisikan sebagai bebas nilai (value free). Dengan kata lain penelitian kuantitatif sangat ketat menerapkan prinsip-prinsip objektifitas. Objektifitas itu diperoleh antara lain melalui penggunaan insutrumen yang diuji validitas dan reliabilitasnya. Metode penelitian kuantitatif dapat diartikan sebagai metode penelitian yang berlandaskan pada filsafat positivisme, digunakan untuk meneliti pada populasi atau sampel tertentu (Arifin, 2020). Objek penelitian ini adalah guru yang mengajar di SMA Negeri 21 Kota Kota Palembang. populasi dalam penelitian ini adalah keseluruhan subjek penelitian yaitu guru yang mengajar di SMA Negeri 21 Palembang berjumlah 70 orang. Sampel penelitian ini peneliti tetapkan sebanyak 50 guru yang menjadi responden penelitian ini. Teknik pengumpulan data pada penelitian ini adalah teknik pengumpulan data pada penelitian ini adalah1) kuesioner, teknik ini digunakan oleh peneliti sebagai instrumen yang berupa daftar pertanyaan yang diajukan pada guru yang mengajar di SMA Negeri 21 Kota Palembang yang meliputi identitas responden, komunikasi interpersonal, disiplin kerja, kinerja guru; 2) dokumentasi yaitu teknik pengumpulan data melalui bagan tertulis yang berupa data sekunder yang berhubungan dengan penelitian yang dilakukan. Studi dokumentasi dilakukan untuk menunjang data yang pada penelitian ini, studi dokumentasi di lakukan di SMA Negeri 21 Kota Palembang; 3) observasi adalah pengamatan yang meliputi kegiatan penguatan perhatian terhadap suatu objek dengan menggunakan seluruh alat indera. Observasi atau pengamatan peneliti lakukan di SMA Negeri 21 Kota Palembang untuk mendapatkan data yang diperlukan pada penelitian ini. Sedangkan metode analisis dan interpretasi data yang pada penelitian ini mengacu pada langkah-langkah analisis yang diajukan oleh Creswell (2016), yang pertama adalah memproses dan menyiapkan data untuk ditinjau; Kedua, membaca seluruh data; Ketiga, Mulai mengkode semua data penelitian; Keempat, mendeskripsikan kategori dan pengaturan tema yang akan dianalisis; Kelima, Menyajikan laporan naratif kualitatif, dan Keenam, Membuat interpretasi dalam penelitian kualitatif.

\section{HASIL DAN PEMBAHASAN}

\section{Pengaruh Komunikasi Interpersonal Terhadap Kinerja Guru di SMA Negeri 21} Palembang

Hasil analisis penelitian ini menunjukan bahwa komunikasi interpersonal memiliki pengaruh yang signifikan terhadap kinerja guru ini mengambarkan bahwa semakin tinggi singnifikannya maka semakin tinggi pula kinerja guru. Hasil ini sesuai dengan penelitian Hadiwijaya (2018), Manalu (2017), Arinato (2006) yang menyatakan komunikasi interpersonal berpengaruh secara signifikan terhadap kinerja guru. Pengujian hipotesis ini penulis menggunakan teknik uji $t$, uji $t$ digunakan untuk mengetahui apakah ada pengaruh parsial secara signifikan antara satu variabel bebas terhadap satu variabel terikat. Dalam hipotesis ini kita dapat melihat dari Nilai thitung $=3,291$ lebih besar dari nilai ttabel 1,671 dengan tingkat signifikan $=0,002<(\alpha) 0.05$, hal ini menunjukan Ho ditolak dan Ha diterima yang bermakna Secara parsial variabel komunikasi interpersonal memiliki pengaruh yang signifikan terhadap variabel kinerja guru di SMA Negeri 21 Palembang, dengan demikian hipotesis ini terbukti. 
Pembuktian ini ditunjukkan bahwa benar salah satu faktor yang menentukan tingkat keberhasilan dan kualitas SMA Negeri 21 Palembang adalah kemampuan guru SMA Negeri 21 Palembang dalam menerapkan komunikasi interpersonal. Keberhasilan dalam menerapkan komunikasi interpersonal pada guru akan meningkatkan paradigma pelayanan yang bermutu kepada para siswa yang merupakan hakikat dalam pencapaian kerja guru tertinggi.

\section{Pengaruh Disiplin Kerja Terhadap Kinerja guru di SMA Negeri 21 Palembang}

Hasil analisis penelitian ini menunjukan bahwa disiplin kerja memiliki pengaruh yang signifikan terhadap kinerja guru ini mengambarkan bahwa semakin tinggi singnifikannya maka semakin tinggi pula kinerja guru. Hasil ini sesuai dengan penelitian Candra (2015), Khaliesah (2009), Maimunah (2006) yang menyatakan komunikasi interpersonal berpengaruh secara signifikan terhadap kinerja guru. Pengujian hipotesis kedua ini penulis menggunakan teknik uji $t$, uji $t$ digunakan untuk mengetahui apakah ada pengaruh parsial secara signifikan antara satu variabel bebas terhadap satu variabel terikat. Dalam hipotesis ini kita dapat melihat dari Nilai thitung =2,941 lebih besar dari nilai ttabel 1,71 (df (n-2) $50-2=48$ adalah sebesar 1,671) dengan tingkat signifikan $=0,002<$ (a) 0.05 , hal ini menunjukan Ho ditolak dan Ha diterima yang bermakna Secara parsial variabel komunikasi interpersonal memiliki pengaruh yang signifikan terhadap variabel kinerja guru di SMA Negeri 21 Palembang, dengan demikian hipotesis ini terbukti.

Pembuktian ini ditunjukkan bahwa benar salah satu faktor yang menentukan tingkat keberhasilan dan kualitas SMA Negeri 21 Palembang adalah kemampuan guru SMA Negeri 21 Palembang Sembawa Kecamatan Sembawa Kabupaten Banyuasin dalam memberikan optimalisasi kompetensi guru di SMA Negeri 21 Palembang dalam menegakkan disiplin. Disiplin kerja guru yang optimal tentu akan meningkatkan kinerja guru dan dengan demikian didapatkan image positif terhadap SMA Negeri 21 Palembang.

\section{Pengaruh Komunikasi Interpersonal dan Disiplin Kerja Terhadap Kinerja guru di SMA Negeri 21 Palembang}

Secara bersama-sama komunikasi interpersonal memiliki pengaruh yang siginifikan terhadap terhadap kinerja guru. Pengujian hipotesis keempat ini penulis menggunakan teknik uji $\mathrm{f}$, uji $\mathrm{f}$ digunakan untuk mengetahui apakah ada pengaruh simultan secara signifikan antara lebih dari satu variabel bebas terhadap satu variabel terikat. Dalam hipotesis ini kita dapat melihat Berdasarkan tabel diatas dengan pengujian dengan menggunakan bantuan SPSS 22 dapat dilihat bahwa Fhitung yang diperoleh adalah 7,329 $>$ Ftabel $=2,81$, dimana $\mathrm{df}=\mathrm{n}-\mathrm{k}-1=50-3-1=46$ adalah sebesar 2,81. dan tingkat kemaknaan secara simultan signifikansinya adalah 0,001 < (a) = 0,05 sehingga Ho ditolak dan Ha diterima. artinya menunjukan bahwa secara bersama-sama (simultan) variabel bebas yaitu komunikasi interpersonal dan disiplin kerja memiliki pengaruh secara simultan yang signifikan terhadap variabel terikat yaitu kinerja guru di SMA Negeri 21 Palembang, hal ini berarti terbukti kebenarannya dan hipotesisnya dapat diterima.

Pembuktian ini ditunjukkan bahwa benar salah satu faktor yang menentukan tingkat keberhasilan dan kualitas kinerja guru di SMA Negeri 21 Palembang adalah dilihat dari komunikasi interpersonal dan disiplin kerja dalam meningkatkan kinerja guru. Semakin baik komunikasi intepersonal yang diterapkan guru SMA Negeri 21 Palembang, maka akan semakin baik pula kinerja guru SMA Negeri 21 Palembang, 
dan semakin baik disiplin kerja yang diterapkan guru SMA Negeri 21 Palembang, maka akan semakin baik pula kinerja guru SMA Negeri 21 Palembang.

Temuan di atas sejalan dengan Rodiah dan Ritonga yang memaparkan bahwa terdapat Pengaruh Komunikasi Interpersonal Terhadap Kinerja Guru, terdapat pengaruh positif dan signifikan komunikasi interpersonal terhadap kinerja guru. sebesar 29,3\% (Rodiah, 2020; Ritonga, 2020). Upaya dalam pencapaian kesuksesan penerapan komunikasi interpersonal pada guru dapat meningkatkan paradigma pelayanan yang bermutu kepada para siswa yang merupakan hakikat dalam pencapaian kerja guru tertinggi.

\section{KESIMPULAN}

Terdapat Pengaruh yang signifikan secara parsial antara komunikasi interpersonal terhadap kinerja guru di SMA Negeri 21 Palembang. Terdapat pengaruh yang signifikan secara parsial antara disiplin kerja terhadap kinerja guru di SMA Negeri 21 palembang. Terdapat Pengaruh yang signifikan secara simultan antara komunikasi interpersonal dan disiplin kerja terhadap kinerja guru di SMA Negeri 21 Palembang.

\section{UCAPAN TERIMAKASIH}

Saya Ucapkan terimakasih kepada tenaga pendidik di SMA Negeri 21 Palembang yang telah yang telah berkontribusi dan memberikan motivasi sehingganya penelitian kami selesai. Terimakasih juga kepada Editorial team Attractive Journal: Innovative Education Journal yang telah memberikan komentar review pada proses review, sehingganya artikel ini layak untuk dipublikasikan.

\section{PERNYATAAN KONTRIBUSI PENELITI}

Penelitian ini merupakan penelitian kolaborasi guru dan dosen. Suyeti Nilasari (SN) adalah peneliti utama yang melakukan penelitian, Happy Fitria (HF) dan Rohana (R) yang membantu dalam menganalisis data serta mengevaluasi kegiatan penelitian.

\section{DAFTAR PUSTAKA}

Andriani, S., Kesumawati, N., \& Kristiawan, M. (2018). The Influence of the Transformational Leadership and Work Motivation on Teachers Performance. International Journal of Scientific \& Technology Research, 7(7). Google Scholar

Arifin, Z. (2020). Metodologi penelitian pendidikan. Jurnal Al-Hikmah, 1(1). Google Scholar

Creswell, J. W. (2016). Research design: pendekatan metode kualitatif, kuantitatif, dan campuran. Yogyakarta: Pustaka Pelajar. Google Scholar

Fitria, H., Kristiawan, M., \& Rahmat, N. (2019). Upaya Meningkatkan Kompetensi Guru Melalui Pelatihan Penelitian Tindakan Kelas. ABDIMAS UNWAHAS, 4(1). Google Scholar

Kartini, D., \& Kristiawan, M. (2019). Pengaruh tunjangan profesi dan motivasi kerja terhadap kinerja guru. Kelola: Jurnal Manajemen Pendidikan,6(1), 25-33. https:// doi.org/10.24246/j.jk.2019.v6.i1.p25-33

Kartini, D., Kristiawan, M., \& Fitria, H. (2020). The Influence of Principal's Leadership, Academic Supervision, and Professional Competence toward Teachers' Performance. International Journal of Progressive Sciences and Technologies (IJPSAT), 20(1), 156-164. Google Scholar 
Kristiawan, M., \& Rahmat, N. (2018). Peningkatan Profesionalisme Guru Melalui Inovasi Pembelajaran. Jurnal Iqra': Kajian Ilmu Pendidikan,3(2), 373-390. https:// doi.org/10.25217/ji.v3i2.348

Mangkunegara, A. (2006). Perencanaan dan Pengembangan Manajemen Sumber Daya Manusia, Pendidikan. PT Refika Aditama. Google Scholar

Marmoah, S. (2016). Administrasi dan supervisi pendidikan teori dan praktek. Deepublish. Google Scholar

Nawawi, A. (2005). Teori Kinerja Dan Pengukurannya. Jakarta: PT. Bumi Aksara. Google Scholar

Peraturan Menteri Negara Pendayagunaan Aparatur Negara dan Reformasi Birokrasi No 16 tahun 2009 Tentang Penilaian Kinerja Guru

Ritonga, B. (2020). Pengaruh Komunikasi Interpersonal, Gaya Kepemimpinan, Budaya Organisasi Terhadap Kinerja Guru Di MAN 2 Model. EduTech: Jurnal Ilmu Pendidikan dan Ilmu Sosial, 6(2), 246-256. https:// doi.org/10.30596/edutech.v6i2.4930

Rivai., \& Basri. (2005). Performance Appraisal: Sistem yang Tepat untuk menilai Kinerja Karyawan dan meningkatkan Daya Saing Perusahaan. Jakarta: Rajagrafindo Persada. Google Scholar

Rodiah, R. S. (2020). Pengaruh Komunikasi Interpersonal Terhadap Kinerja Guru Di Smk Negeri 1 Bandung (Doctoral dissertation, Universitas Pendidikan Indonesia). Google Scholar

Sakban, S., Nurmal, I., \& Ridwan, R. B. (2019). Manajemen sumber daya manusia. Alignment: Journal of Administration and Educational Management, 2(1), 93-104. Google Scholar

Siagian, S. (2003). Teori dan Praktek Kepemimpinan (cetakan kelima). Jakarta: Rineka Cipta.Google Scholar

Yuliandri, J., \& Kristiawan, M. (2017). Peran Kepemimpinan Kepala Sekolah Terhadap Peningkatan Kinerja Guru. Jurnal Dosen Universitas PGRI Palembang. Google Scholar

Copyright Holder :

(C) Nilasari, S., Fitria, H., \& Rohana, R., (2020).

First Publication Right :

(c) Attractive : Innovative Education Journal

This article is under:

()(1) (2) 